\title{
PEMANFAATAN TEKNOLOGI GOOGLE MAPS API UNTUK APLIKASI PENDETAKSIAN LOKASI RAWAN KRIMINALITAS BERBASIS ANDROID KECAMATAN PRAYA TIMUR, KABUPATEN LOMBOK TENGAH
}

\author{
M Lukman Hakim ${ }^{1}$, Wire Bagye ${ }^{2}$, Hairul Fahmi ${ }^{3}$, Khairul Imtihan ${ }^{4}$, \\ 1,2,3,4 Program Studi Teknik Informatika, STMIK Lombok \\ Jln. Basuki Rahmat No.105 Praya Lombok Tengah 83511
}

${ }^{1} \underline{\text { lukman821@gmail.com }}{ }^{2} \underline{\text { wirestmik@gmail.com }}{ }^{3}$ iroel.ami@gmail.com, ${ }^{4} \underline{\text { khairulimtihan31@gmail.com }}$

\begin{abstract}
East Praya is one of 12 (twelve) districts in Central Lombok Regency, West Nusa Tenggara Province (NTB) with a total population of 53,753 people recorded in the Permanent Voter List (DPT) on April 19, 2018. With the density of the population, the level of competition for a decent life is very high. There are many local people who commit crimes as an alternative way to fulfill their needs. Crime can occur in various places and with different times which makes it difficult to identify areas that are high-levels possibility of crime.

In this research, the researcher attempts to analyze the existing problems as well as to provide a solution about locations that have a high level of crime. This research used information system development method called SDLC. This research also used a design process models named UML model, database design, interface design, Google Maps API and relation between tables.

The result of this research was an Android-based tool or application that aims to provide information to the public about the location of points that have a high level of crime.The application could send a report to the local police regarding the occurrence of criminal acts that are currently occurred. In addition, the researcher also expects for future development of this application.
\end{abstract}

Keywords : East Praya, Android, Crime, Google Maps API, SDLC

\begin{abstract}
Abstrak
Praya Timur merupakan salah satu dari 12 (dua belas) kecamatan yang ada di Kabupaten Lombok Tengah, Provinsi Nusa Tenggara Barat ( NTB ) dengan jumlah penduduk yang tercatat dalam Daftar Pemilih Tetap ( DPT ) pada tanggal 19 April 2018 sebanyak 53.753 jiwa. Dengan kepadatan jumlah penduduk tersebut, tingkat persaingan untuk mendapatkan kehidupan yang layak sangatlah tinggi. Tidak sedikit dari masyarakat setempat melakukan tindak kriminal sebagai alternatif lain untuk memanuhi kebutuhan hidup mereka. Kejahatan tindak kriminal bisa terjadi di berbagai tempat dan dengan waktu kejadian yang berbeda yang memebuat sulitnya untuk mengetahui daerah yang memiliki tingkat kerawanan tindak kriminial yang tinggi.

Pada penelitian ini, peneliti mencoba untuk menganalisis pokok - pokok permasalahan yang ada, dan mencoba untuk memberikan sebuah solusi yang dapat memberikan informasi mengenai lokasi yang memiliki tingkat kerawanan tindak kriminal yang tinggi. Menggunakan metode pengembangan sistem informasi SDLC. Melakukan perancangan model proses menggunakan model UML, perancangan database, perancangan interface dan relasi antar tabel serta teknologi Google Maps Api.

Solusi yang dihasilkan merupakan sebuah alat atau aplikasi berbasis Android yang ditujukan untuk memberikan informasi kepada masyarakat mengenai titik lokasi yang memiliki tingkat kerawanan tindak kriminal yang tinggi. Disamping itu, peneliti juga mengharapkan untuk pengembangan di masa mendatang, aplikasi mampu mengirimkan sebuah laporkan mengenai kejadian tindak kriminal yang sedang maupun yang telah terjadi kepada pihak kepolisian setempat.
\end{abstract}

Kata kunci :, Praya Timur, Android, Kriminal, Google Maps API, SDLC 


\section{PENDAHULUAN}

Praya Timur merupakan salah satu dari 12 (dua belas) kecamatan yang ada di kabupaten Lombok Tengah, Nusa Tenggara Barat (NTB). Secara geografis, Kecamatan Praya Timur Terletak pada titik koordinat (-8.8001543, 116.3092372) dengan batas - batas wilayah yaitu Sebelah Utara: Kecamatan Janapria, Sebelah Selatan: Laut Bali dan Kecamatan Pujut, Sebelah Barat : Kecamatan Praya Tengah dan Sebelah Timur : Kabupaten Lombok Timur.

Jumlah penduduk di kecamatan Praya Timur yang terdaftar di dalam DPT ( Daftar Pemilih Tetap ) Komisi Pemilihan Umum (KPU) Kabupaten Lombok Tengah pada tanggal 19 April 2018 sejumlah 53.753 jiwa dengan jumlah laki laki sebanyak 26.401 jiwa dan perempuan sejumlah 27.352 jiwa. Dengan kepadatan jumlah penduduk tersebut, tingkat persaingan untuk mendapatkan kehidupan yang layak sangatlah tinggi. Berbagai hal dilakukan masyarakat setempat agar kebutuhan ekonominya terpenuhi. Tidak sedikit dari masyarakat setempat melakukan tindakan kriminal sebagai alternatif lain untuk memenuhi kebutuhan ekonomi mereka.

Salah satu jenis kejahatan tindak kriminal yang sering terjadi yaitu pembegalan dan masuk kedalam kategori kejahatan tindak kriminal di jalan. Kejahatan tindak kriminal bisa terjadi di berbagai tempat dan dengan waktu kejadian yang berbeda. Hal tersebut membuat sulitnya untuk mengetahui daerah yang memiliki tingkat kerawanan tindak kriminal yang tinggi. Informasi mengenai lokasi maupun tindakan kejahatan yang sering terjadi merupakan informasi yang penting untuk diketahui masyarakat setempat serta penegak hukum khususnya jajaran kepolisian di daerah kecamatan Praya Timur, kabupaten Lombok Tengah, Nusa Tenggara Barat (NTB).

Android merupakan salah satu sistem operasi yang ditanamkan di dalam sebuah Smartphone. Smartphone dengan sistem operasi Android merupakan telepon pintar yang paling banyak digunakan pada waktu ini. Selain itu, Google Maps API merupakan sebuah library atau tool yang disediakan oleh Google untuk membantu para pengembang aplikasi demi melakukan pemetaan digital terhadap wilayah di seluruh dunia. Dengan demikian, pemanfaatan teknologi informasi cukup diperlukan untuk dapat membantu memecahkan masalah kriminalitas pada suatu daerah khususnya di daerah kecamatan Praya Timur dengan cara membangun sebuah aplikasi yang mampu menyediakan informasi serta mendeteksi lokasi daerah rawan tindak kriminal yang berbasis Android dengan pemanfaatan teknologi Google Maps API.

\section{Tinjuan Pustaka}

Hilman (2015) dalam penelitiannya tentang Pemetaan Daerah Rawan Kriminalitas Di Wilayah Hukum Poltabes Semarang Dengan Menggunakan Metode Clustering. Melakukan analisa dan implemementasi sistem yang menggunakan software statistika untuk proses analisa dan menggunakan software SIG untuk proses pemetaan. Adapun metode yang digunakan adalah cluster untuk melakukan proses pengelompokan dalam menentukan tingkat kerawanan suatu daerah. Hasil dari penelitan yang dilakukan yaitu, aplikasi mampu mengelompokan beberapa daerah rawan kriminalitas di Kota Semarang dan menyatakan bahwa keamanan di Kota Semarang cendrung rawan di sekitar pusat kota dibandingkan dengan wilayah pinggiran kota. Penelitian yang dilakukan saat ini berbeda dari sisi objek penelitian, selain itu penelitian saat ini manghasilkan sebuah aplikasi yang dapat menampilkan notifikasi kepada pengguna ketika pengguna berada pada lokasi rawan kriminalitas sesuai data yang didapatkan.

Yuwono (2015) dalam penelitiannya tentang Sistem Informasi Geografis Berbasis Android Untuk Pariwisata Di Daerah Magelang. Menghasilkan sebuah aplikasi berbasis android yang terhubung langsung dengan Google Maps API yang bertujuan untuk memberikan informasi mengenai lokasi pariwisata di Daerah Magelang dengan mudah dan sederhana karena dapat dioperasikan dimanapun pengguna berada karena menggunakan piranti mobile device berbasis android. Aplikasi berhasil menyajikan informasi pariwisata dan lokasi terdekat dari posisi pengguna. Penelitian yang dilakukan saat ini berbeda dengan penelitian yang dilakukan oleh Yuwono. Penelitian saat ini memanfaatkan teknologi untuk melakukan pemetaan digital terhadap titik lokasi rawan kriminalitas dan memanfaatkan teknologi geofencing untuk melakukan pendeteksian ketika pengguna masuk dan keluar dari daerah kriminalitas tersebut.

Meriana (2015) dalam penelitiannya tentang Perancangan Sistem Informasi Daerah Rawan Kriminalitas di Kabupaten Lahat. 
Menghasilkan Sistem Informasi Geografis (SIG) untuk melakukan pemetan daerah rawan rawan kriminalitas berbasis sistem informasi geografis di kota Palembang Kabupaten Lahat dengan menggunakan Macromedia Dreamweaver 8 dan bahasa pemrograman PHP. Metode penelitian yang digunakan yaitu Metodelogi Prototyping dan menggunakan tool pemodelan UML (Unified Modelling Language J serta memanfaatkan teknologi Google Maps API untuk menampilkan peta GIS (Geographyc Information System ). Sistem informasi ini hanya sebatas menampilkan informasi mengenai titik lokasi rawan kriminalitas, hal ini berbeda dengan penelitian saat ini yaitu menghasilkan aplikasi berbasis android yang dapat menampilkan informasi mengenai titik lokasi rawan kriminal serta menampilkan notifikasi kepada pengguna ketika masuk dan keluar dari daerah rawan kriminalitas.

Andi (2015) dalam penelitiannya tentang Pembangunan Aplikasi Child TrackerBerbasis Assisted-Global Positioning System (A-GPS) Dengan Platform Android. Menghasilkan perangkat lunak yang mampu mengetahui keberadaan anak secara jarak jauh hanya dengan menggunakan mobile Android. Teknolgi yang digunakan yaitu A-GPS (Assisted Positioning System) dan Google Maps API. Perbedaan penelitian saat ini dengan penelitian yang dilakukan oleh Andi terletak pada output yang dihasilkan yaitu aplikasi mampu menampilkan informasi mengenai titik lokasi rawan kriminalitas.

Suwandi (2016) dalam penelitiannya tentang Sistem Informasi Pemantauan Kinerja Sales Memanfaaatkan Monitoring Geofencing dan Teknologi Cloud Message Berbasis Mobile. Menghasilkan perangkat lunak yang mampu memberikan informasi mengenai daerah - daerah serta rute yang dilalui oleh seorang sales untuk memperoleh informasi mengenai kinerja dari sales tersebut. Perbedaan pada penelitian saat ini yaitu terletak pada pemanfaatan teknologi geofencing. Pada penelitian saat ini, memanfaatkan teknologi geofencing untuk melakukan monitoring serta memberikan notifikasi atau pemberitahuan kepada pengguna ketika masuk dan keluar dari daerah rawan kriminalitas.

Rismayani (2016) dalam penelitiannya tentang Pemanfaatan Teknologi Google Maps API Untuk Aplikasi Laporan Kriminal Berbasis Android Pada Polrestabes Makassar. Metode atau teknologi yang digunakan dalam penelitiannya yaitu teknologi Google Maps API. Hasil dari penelitiannya adalah dengan adanya aplikasi tersebut, masyarakat setempat dapat melaporkan tindak kriminal yang terjadi di lokasi kejadian tanpa harus datang langsung ke kantor polisi, selain itu aplikasi tersebut dapat memudahkan aparat kepolisisan untuk melihat laporan kriminal dari masyarakat dengan melihat gambar dan lokasi kejadian kriminal yang dikirimkan. Selain pada lokasi, perbedaan perbedaan penelitian ini dengan penelitian yang penulis lakukan yaitu penerapan teknologi geofencing untuk menampilkan notifikasi kepada pengguna ketika masuk dan keluar pada titik lokasi rawan kriminalitas.

Kholil (2017) dalam penelitiannya tentang Pemanfaatan Sistem Informasi Geografis (SIG) Dalam Aplikasi Pelaporan Dan Pelacakan Kejahatan Berbasis Android. Hasil dari penelitiannya yaitu aplikasi mampu digunakan untuk proses pelaporan dan pelacakan secara realtime melalui smartphone berbasis android. Selain itu, metode geofencing memungkinkan proses kejahatan yang mendesak bisa lebih cepat ditangani kerena aplikasi melakukan pendeteksian kejadian kriminal sekitar dalam jarak sepuluh kilometer. Perbedaan penelitian saat ini dengan penelitian yang dilakukan oleh Kholil yaitu aplikasi yang dihasilkan selain dapat melakukan pendeteksian lokasi rawan kriminalitas, aplikasi juga menampilkan informasi mengenai detail lokasi rawan tindak kriminalitas berupa nama lokasi, jumlah kejadian yang pernah terjadi serta wakti sering terjadinya kejadian tindak kriminalitas tersebut.

\section{METODOLOGI PENELITIAN}

\section{A. Alur Penelitian}

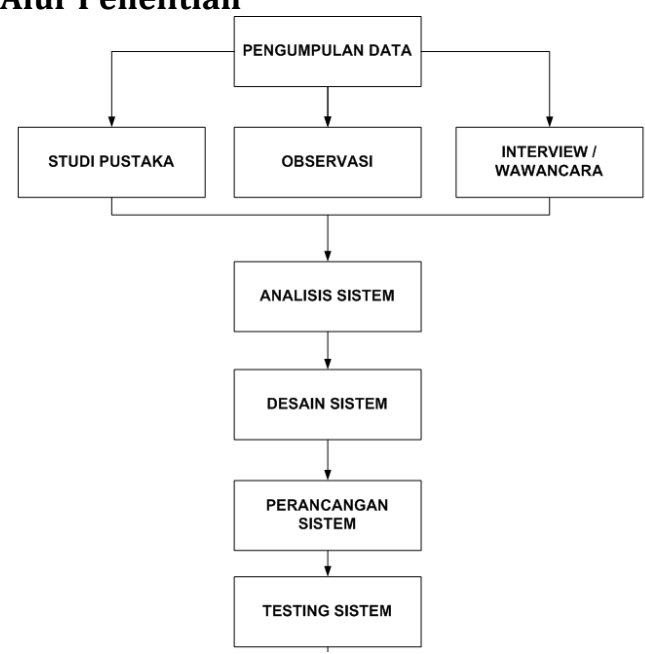

Gambar 1 Alur Penelitian 
a. Pengumpulan data

Adapun metode pengumpulan data dilakukan yaitu sebagai berikut:

1. Studi pustaka yaitu proses pengumpulan data yang dilakukan dengan cara membaca beberapa referensi dari berbagai sumber seperti buku, jurnal, artikel - artikel yang terkait.

2. Wawancara yang dilakukan dengan caramenanyakan langsung kepada narasumber mengenai data atau informasi yang ingin didapatkan.

3. Observasi yang dilakukan dengan cara mengamati lokasi daerah yang sering terjadinya tindak kriminal. Adapun hasil dari pengamatan atau observasi dapat dilihat pada Tabel 1.

Tabel 1 Hasil Observasi

\begin{tabular}{|c|l|r|}
\hline No & \multicolumn{1}{|c|}{ Lokasi } & Koordinat \\
\hline \multirow{4}{*}{1} & Desa Ganti, Kec. & \\
& Praya Timur, & $(-8.7695604$, \\
& Kab. Lombok & $116.402427)$ \\
& Tengah ( NTB ) & \\
\hline \multirow{5}{*}{2} & Desa Ganti, Kec. & \\
& Praya Timur, & $(-8.771789$, \\
& Kab. Lombok & $116.4182904)$ \\
& Tengah ( NTB ) & \\
\hline \multirow{2}{*}{3} & Desa Mujur, Kec. & \\
& Praya Timur, Kab. & $(-8.754075$, \\
& Lombok Tengah ( & $116.341160)$ \\
& NTB ) & \\
\hline
\end{tabular}

b. Analisis Sistem

Dalam penelitian ini metode analisa yang digunakan yaitu metode Analisis SWOT untuk mendapatkan informasi dari analisis situasi dan memisahkannya dalam pokok persoalan internal (kekuatan dan kelemahan) dan pokok persoalan eksternal (peluang dan ancaman).

c. Desain Sistem

Setelah dilakukannya proses analisa sistem, pada tahap ini peneliti melakukan proses desain sistem mulai dari proses desain database, relasi antar tabel, dan desain interface untuk aplikasi yang akan di kembangkan.

d. Perancangan Sistem

Pada tahap ini peneliti melakukan proses pengerjaan aplikasi sesuai dengan tahap desain yang sebelumnya dilakukan mulai dari memasukan data - data yang di dapatkan ke dalam database yang selanjutnya di ikuti dalam proses menulis kode atau alogritma program yang telah di tentukan pada proses analisa sistem sebelumnya.

e. Testing Sistem

Pada tahap ini, peneliti melakukan proses testing terhadap aplikasi yang sudah dibuat sebelum di implementasikan ke pengguna. Pada tahap testing, peneliti melakukan pengujian dalam segi fungsionnalitas dari aplikasi tersebut

B. Arsitektur Sistem

Arsitektur sistem atau gambaran umum dari aplikasi yang dibuat pada penelitian ini ditunjukan pada gambar 2

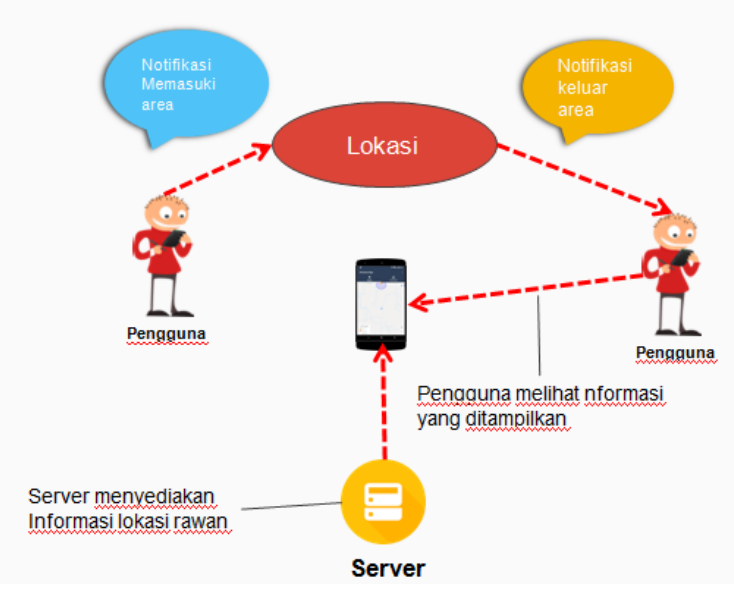

Gambar 2 Arsitektur Sistem

Pada gambar 2 menjelaskan mengenai aristektur dari aplikasi pendeteksian lokasi rawan kriminalitas, pada arsitektur tersebut pengguna akan ditampilkan notifikasi jika masuk dan keluar dari daerah rawan kriminalitas, selain itu pengguna dapat melihat informasi mengenai titik lokasi rawan kriminalitas yang disediakan oleh server dan diakses menggunakan aplikasi yang terinstall pada smartphone android.

\section{HASIL DAN PEMBAHASAN}

Adapun hasil yang dan pembahasan dari penelitian yang telah dilakukan ditunjukan pada gambar 3 mengenai sistem Use Case Diagram menampilkan aktor yang menggunakan sistem yaitu user dan administrator. Admin mampu menginput, menghapus dan mengedit data kejadian tindak kriminal yang kemudian disimpan di database untuk selanjutnya diolah oleh sistem sehingga dapat menampilkan informasi kepada user atau peengguna aplikasi. Pengguna dapat melihat informasi berupa peta 
dan detail kejadian kriminal sesuai lokasi yang dipilih, selain itu user dapat menerima notifikasi atau pemberitahuan ketika memasuki daerah rawan tindak kriminal sesuai dengan area lokasi yang dimasuki. User dapat masuk ke halaman utama aplikasi setelah melakukan proses login dan registrasi akun.

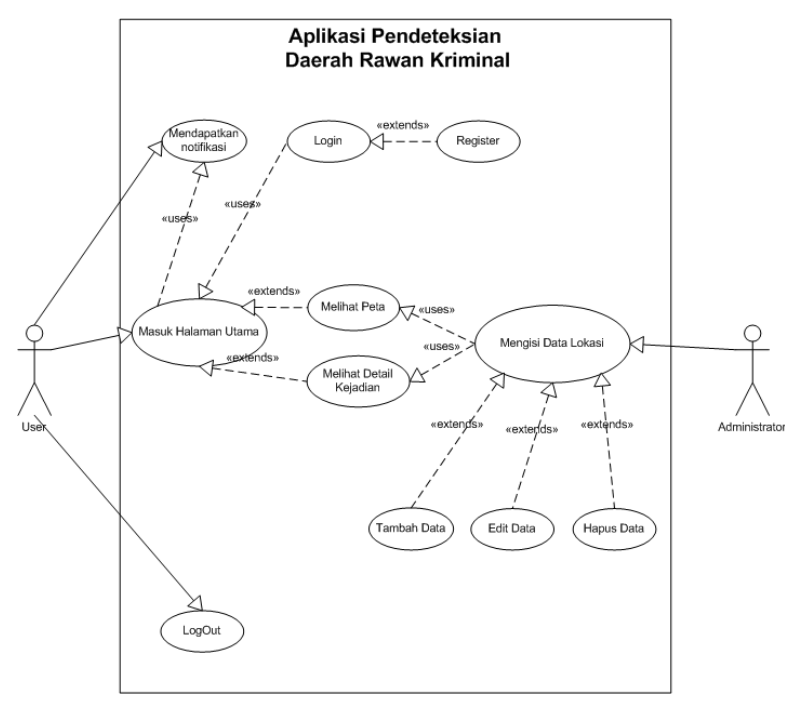

Gambar 3 Use Case Diagram Sistem

a. Activity Diagram Proses Menerima Notifikasi

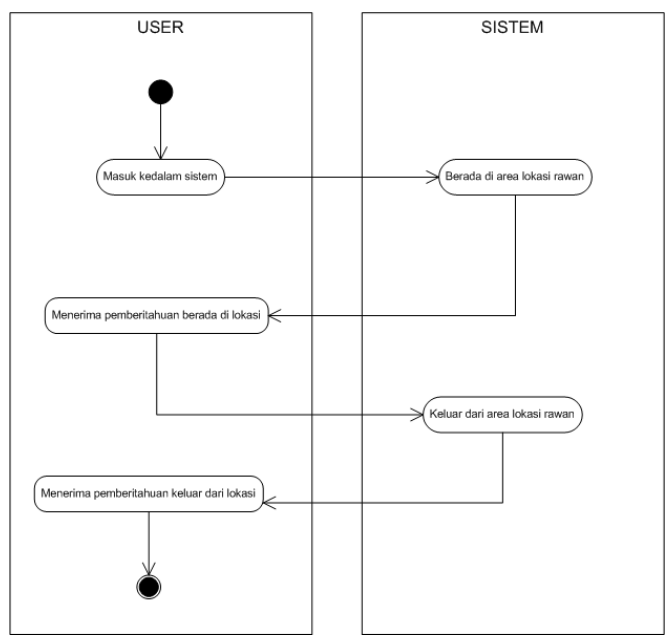

Gambar 4 Activity Diagram Proses Menerima Notifikasi

Gambar 3.6 diatas menunjukan bagaimana proses untuk menerima notifikasi yakni oleh user masuk kedalam sistem, dan kemudian oleh sistem mendapatkan titik koordinat lokasi dari user. Selanjutnya, ketika user masuk atau berada di dalam area lokasi, oleh sistem mengirim pemberitahuan ke user bahwa user telah berada pada area lokasi kriminalitas. Begitupun sebaliknya, ketika user keluar dari area lokasi rawan kriminalitas, oleh sistem mengirim pemberitahuan ke user bahwa user telah keluar dari area lokasi rawan kriminal.

b. Activity Diagram Pengolahan Data oleh Admin

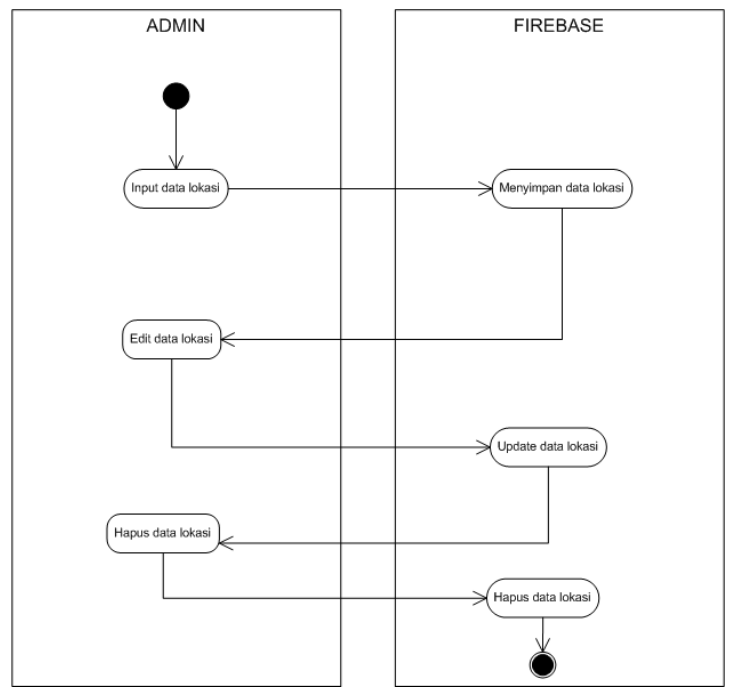

Gambar 5 Activity Diagram Pengolahan Data oleh Admin

Gambar 5 menunjukan bagaimana proses pengolahan data oleh admin yakni oleh admin melakukan proses penginputan data ke dalam sistem yang selanjutnya disimpan di database firbase. Setelah itu, oleh admin mampu melakukan proses update maupun delete data yang sebelumnya sudah di inputkan

\section{c. Firebase Realtime Database}

() https://kriminalapp-31dc8.firebaseio.com/

$$
\begin{aligned}
& \text { kriminalapp-31dc8 } \\
& \text { †... lokasi_kejadian } \\
& \text { †..... user_location }
\end{aligned}
$$

Gambar 6 Firebase Realtime Database 
Gambar 6 menunjukan hasil penyimpanan data yang menggunakan teknologi Firebase Realtime Database yang merupakan database yang di host pada cloud. Karena proses penyimpanan data menggunakan teknologi Firebase, maka data yang di simpan adalah dalam bentuk objek JSON, oleh karena itu, database tersebut tidak memilki tabel atau catatan.

d. Tampilan Halaman Login

Halaman login digunakan sebagai proses authentification atau proses pengecekan akun sebagai syarat untuk dapat masuk ke halaman utama aplikasi. Tampilan halaman login dapat dilihat pada gambar 7

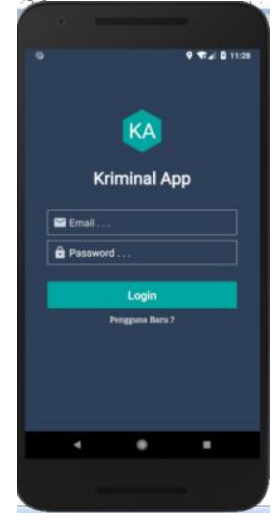

Gambar 7 Tampilan Halaman Login

e. Tampilan Halaman Registrasi

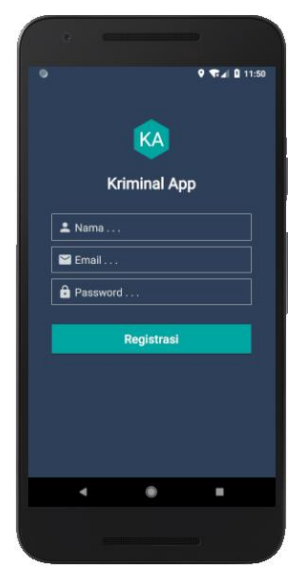

Gambar 8 Tampilan Halaman Registrasi

Halaman registrasi digunakan untuk melakukan pendaftaran akun baru oleh user atau pengguna

f. Tampilan Halaman Utama

Halaman utama merupakan halaman yang akan ditampilkan oleh aplikasi ketika user sudah berhasil login.

ISSN. 2620-6900 (Online) 2620-6897 (Cetak)

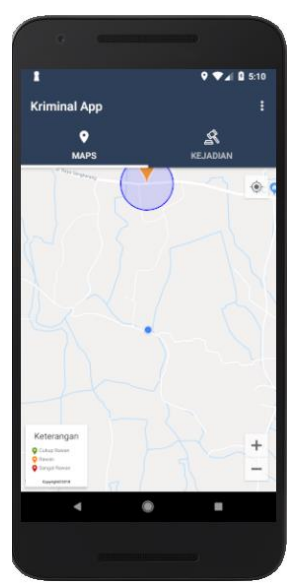

Gambar 9 Tampilan Halaman Utama

g. Tampilan Halaman Informasi Lokasi

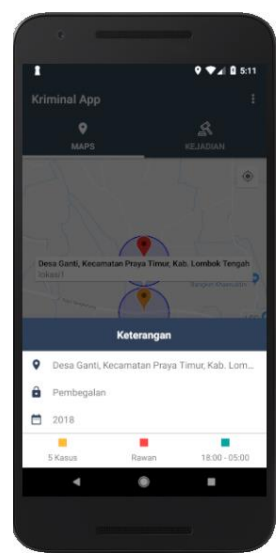

Gambar 10 Tampilan Informasi Lokasi

Pada halaman Informasi Lokasi, pengguna akan ditampilkan megenai informasi dari lokasi yang telah dipilih

h. Tampilan Halaman List Kejadian

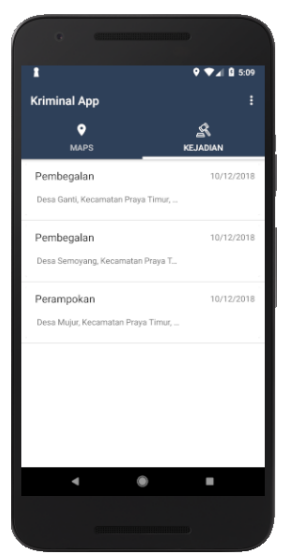

Gambar 11 Tampilan Halaman List Kejadian 
Pada halaman ini, pengguna dapat melihat list - list kejadian apa saja yang sudah terjadi beserta informasi mengenai lokasi dari kejadian tersebut.

i. Tampilan Halaman Notifikasi
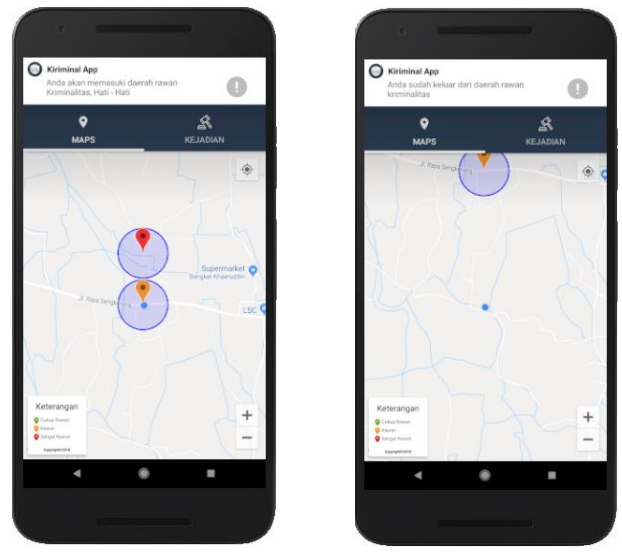

Gambar 12 Notifiikasi Masuk dan Keluar

Halaman Notifikasi merupakan halaman yang akan ditampilkan oleh aplikasi ketika user masuk atau keluar dari daerah lokasi rawan kriminalias yang sudah terdata atau tersimpan dalam database sistem. Pesan dari notifikasi yang ditampilkan berbeda sesuai status dari pengguna apakah Akan / Sudah memasuki daerah tersebut maupun status pengguna yang sudah keluar dari lokasi daerah rawan kriminalitas tersebut.

j. Tampilan Halaman Input Profil

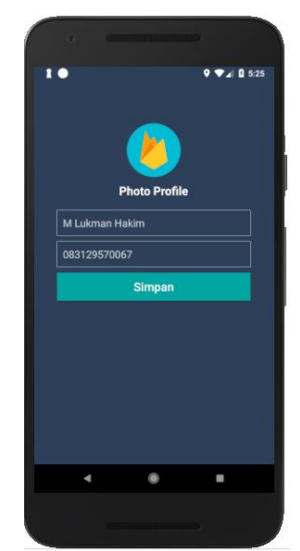

Gambar 13 Tampilan Input Profil

Halaman Input profil digunakan untuk melakukan penginputan atau perubahan terhadap data profil akun dari masing - masing pengguna

k. Pengujian

Alat yang digunakan untuk melakukan pengujian dengan metode Black Box Tesing ini yaitu sebuah library dengan nama esspresso yang dimana library tersebut secara default sudah disematkan pada Android Studio untuk membantu para pengembang dalam melakukan uji coba terhadap fungsi dari aplikasi yang dikembangkan. Adapun hasil pengujian terhadap aplikasi dapat dilihat pada Tabel 2 .

Tabel 2 Pengujian Black Box

\begin{tabular}{|c|c|l|c|}
\hline No & Kelas Uji & \multicolumn{1}{|c|}{$\begin{array}{c}\text { Hasil yang } \\
\text { diharapkan }\end{array}$} & Kesimpulan \\
\hline 1 & Login & $\begin{array}{l}\text { Berhasil login } \\
\text { ke } \\
\text { menggunakan } \\
\text { data yang } \\
\text { tersimpan }\end{array}$ & Valid \\
\hline 2 & $\begin{array}{l}\text { Input } \\
\text { Profil }\end{array}$ & $\begin{array}{l}\text { Berhasil input } \\
\text { profil masing - } \\
\text { masing } \\
\text { pengguna }\end{array}$ & Valid \\
\hline 3 & Registrasi & $\begin{array}{l}\text { Berhasil } \\
\text { melakukan } \\
\text { proses } \\
\text { registrasi } \\
\text { masing } \\
\text { masing } \\
\text { pengguna }\end{array}$ & Valid \\
\hline 5 & Halaman & $\begin{array}{l}\text { Berhasil } \\
\text { menampilkan } \\
\text { halaman } \\
\text { utama }\end{array}$ & Valid \\
\hline Logout & $\begin{array}{l}\text { Proses logout } \\
\text { atau keluar } \\
\text { dari aplikasi } \\
\text { oleh user }\end{array}$ & Valid \\
\hline
\end{tabular}

\section{Kesimpulan dan saran}

A. Kesimpulan

Adapun Kesimpulan dari penelitian yang telah diakasanakan yaitu aplikasi dapat membantu dalam menyajikan informasi mengenai lokasi - lokasi rawan tindak kriminalitas di jalan raya. Selain itu aplikasi dapat menampilkan notifikasi atau pemberitahuan ketika pengguna masuk dan keluar dari daerah rawan kriminalitas tersebut.

\section{B. Saran}

Adapun saran yang perlu diperhatikan dalam proses pengembangan aplikasi ini yaitu: 
1. Aplikasi dapat dikembangkan sehingga mampu melakukan proses pengiriman laporan mengenai kejadian tindak kriminal ke aparat kepolisian terdekat.

2. Aplikasi dapat dikembangkan sehingga kompetibel dengan versi android di bawah 5.0 (Lolipop)

3. Aplikasi dapat dikembangkan sehingga terkoneksi dengan web services

4. Aplikasi dapat dikembangkan sehingga mampu menampilkan jarak antara lokasi kejadian dengan lokasi pengguna

5. Aplikasi dapat dikembangkan sehingga mampu menampilkan detail kejadian dari masing - masing item.

\section{Daftar Pustaka:}

[1] Dharwiyanti, S., Wahyono, R.,S., 2013, Pengantar Unified Modeling Language ( UML ), Kuliah Umum IlmuKomputer.com

[2] Hilman, Y., G., 2015, Pemetaan Daerah Rawan Kriminalitas Di Wilayah Hukum Poltabes Semarang Tahun 2013 Dengan Menggunakan Metode Clustering, Jurnal Geodesi Undip Vol. 4, No 1.

[3] Juansyah, A., 2015, Pembangunan Aplikasi Child Tracker Berbasis Assisted-Global Positioning System (A-GPS) Dengan Platform Android, Jurnal Ilmiah Komputer dan Informatika (KOMPUTA) Edisi. 11 Agustus 2015 ISSN: 2089-9033.

[4] Kholil, 2017, Pemanfaatan Sistem Informasi Geografis (SIG) Dalam Aplikasi Pelaporan Dan Pelacakan Kejahatan Berbasis Android. Jurnal Teknologi Informasi dan Komunikasi Vol. 6 No.1, Juni 2017: 51 - 58.

[5] Ladjamudin bin, Al Bahra. 2009. Analsis dan Desain Sistem Informasi.Yogyakarta: Graha Ilmu.
[6] Meriana, Mirza, A., H., Bakti, A., M., 2015. Perancangan Sistem Informasi Daerah Rawan Kriminalitas di Kabupaten Lahat. Seminar Hasil Penelitian Sistem Informasi dan Teknik Informatika ke-1(SHaPSITI2015).

[7] Rismayani. 2016. Pemanfaatan Teknologi Google Maps API Untuk Aplikasi Laporan Kriminal Berbasis Android Pada Polrestabes Makassar. Jurnal Penelitian Pos dan Informatika Vol. 6, No 2, (2016) 185 - 200.

[8] Svennerberg, G., 2010. Beginning Google Maps API 3. Apress.

[9] Suwandi, 2016, Sistem Informasi Pemantauan Kinerja Sales Memanfaaatkan Monitoring Geofencing dan Teknologi Cloud Message Berbasis Mobile. Journal of Information and Technology Vol. 04, No 01, 2016. ISSN: 2303-1425.

[10] Yuwono, B., Aribowo, A., S., Setyawan, F., A., 2015. Sistem Informasi Geografis Berbasis Android Untuk Pariwisata Di Daerah Magelang. Seminar Nasional Informatika 2015 (semnasIF 2015). UPN "Veteran" Yogyakarta, 14 November 2015 ISSN: 19792328.

[11] Bagye, W., \& Yuliana, Y. (2018). Implementasi Greenfoot 3.0. 4 Untuk Membangun Aplikasi Pengucapan Bahasa Inggris Pada Arrobbany Course. Jurnal Informatika dan Rekayasa Elektronik, 1(1), 25-32.

[12] Bagye, W., \& Najamudin, N. (2018). APLIKASI PENGHITUNG JUMLAH PAKAN SAPI POTONG BERBASIS ANDROID. Jurnal Informatika dan Rekayasa Elektronik, 1(2), 40-46. 